JPSCR: Journal of Pharmaceutical Science and Clinical Research, 2021, 01, 74-81

DOI: $10.20961 /$ jpscr.v6i1.39540

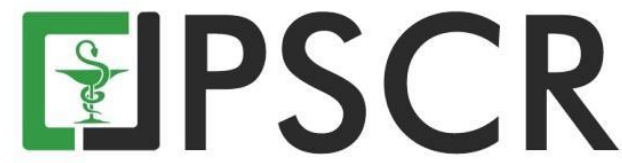

\title{
Aktivitas sitotoksik dan ekspresi protein p53 dan bcl-2 ekstrak dan fraksi daun yakon (Smallanthus sonchifolius) terhadap sel kanker T47D
}

\author{
Lidia Kurniawati Imanuel $^{* 1}$, Titik Sunarni² ${ }^{2}$ an Wiwin Herdwiani² \\ ${ }^{1}$ Program Studi Farmasi, Universitas Setia Budi, Jl. Letjend Sutoyo, Surakarta, Indonesia, 57127 \\ ${ }^{2}$ Fakultas Farmasi, Universitas Setia Budi, Jl. Letjend Sutoyo, Surakarta, Indonesia 57127 \\ *email korespondensi: herdwiani@ setiabudi.ac.id
}

Received 31 January 2020, Accepted 9 January 2021, Published 15 March 2021

\begin{abstract}
Abstrak: Daun yakon ialah tanaman yang bisa dijadikan sebuah alternatif pengobatan kanker. Tujuan dari studi ini guna mengetahui aktivitas sitotoksik ekstrak etanol $70 \%$ daun yakon (Smallanthus sonchifolius) beserta fraksinya yaitu fraksi n-heksan, fraksi etil asetat dan fraksi air pada sel T47D dan mengetahui pengaruh ekspresi protein p53 dan bcl-2 pada pemberian fraksi aktif daun yakon. Ekstrak didapatkan dengan metode soxhletasi melalui pelarut etanol 70\%. Ekstrak etanol kemudian difraksinasi melalui partisi cair-cair. Uji sitotoksik melalui penggunaan sel kanker T47D dan sel vero melalui metode MTT assay dan absorbansinya dibaca dengan ELISA reader. Untuk mengetahui pengaruh ekspresi protein p53 dan bcl-2 dilakukan uji imunositokimia. Hasil penelitian menunjukkan bahwa ekstrak dan fraksi etil asetat daun yakon mempunyai aktivitas sitotoksik pada sel kanker T47D dalm perolehan nilai $\mathrm{IC}_{50} 71,77 \mu \mathrm{g} / \mathrm{ml}$ dan $60,86 \mu \mathrm{g} / \mathrm{ml}$, sementara fraksi air dan fraksi n-heksan tidak mempunyai aktivitas sitotoksik melalui nilai $\mathrm{IC}_{50}>100 \mu \mathrm{g} / \mathrm{ml}$. Ekstrak daun yakon dapat mengembangkan ekspresi protein p53 dan bcl-2 terhadap konsentrasi 35,88 $\mu \mathrm{g} / \mathrm{ml}-143,54 \mu \mathrm{g} / \mathrm{ml}$ dan fraksi etil asetat dapat mengembangkan ekspresi protein p53 dan bcl-2 dalam konsentrasi 35,88 $\mu \mathrm{g} / \mathrm{ml}$ $121,72 \mu \mathrm{g} / \mathrm{ml}$.
\end{abstract}

Kata kunci: Yakon; Sitotoksik; Ekspresi protein

Abstract. Cytotoxicity activity and protein expression of p53 and bcl-2 for extract and fractions of yakon leaves (Smallanthus sonchifolius) against cancer cell lines T47D. Yacon leaves are plants that can be used as an alternative cancer treatment. This study aimed to determine the cytotoxic activity of $70 \%$ ethanol extract of yakon leaves (Smallanthus sonchifolius) and their fractions namely n-hexane fraction, ethyl acetate fraction and water fraction on T47D cells and determine the effect of p53 and bcl-2 protein expression on the administration of active yakon leaf fraction. The extract was obtained by the soxhlation method with $70 \%$ ethanol solvent. Ethanol extract was then fractionated with liquid-liquid partition. Cytotoxic tests were carried out using T47D cancer cells and vero cells with the MTT assay method and the absorbance was read with an elisa reader. To determine the effect of p53 and bcl-2 protein expression, immunocytochemical tests were performed. The results showed that ethanol extract and ethyl acetate fraction of yakon leaf had cytotoxic activity against T47D cancer cells with $\mathrm{IC}_{50}$ values of $71.77 \mu \mathrm{g} / \mathrm{ml}$ and $60.86 \mu \mathrm{g} / \mathrm{ml}$, while the water fraction and $\mathrm{n}$ hexane fraction did not have cytotoxic activity with an $\mathrm{IC}_{50}$ value $>100 \mu \mathrm{g} / \mathrm{ml}$. Yakon leaf extract was able to increase the expression of $\mathrm{p} 53$ and bcl-2 protein at a concentration of 35.88 $\mu \mathrm{g} / \mathrm{ml}-143.54 \mu \mathrm{g} / \mathrm{ml}$ and the ethyl acetate fraction increased the expression of p53 and bcl-2 proteins at a concentration of $35.88 \mu \mathrm{g} / \mathrm{ml}-121.72 \mu \mathrm{g} / \mathrm{ml}$.

Keywords: Yacon; Cytotoxic; Protein expression 


\section{Pendahuluan}

Kanker ialah faktor utama yang mengakibatkan kematian di semua penjuru dunia. Berdasarkan hasil Rikerdas pada tahun 2018, angka prevalensi kanker di Indonesia ialah 1,8\% (per mil), atau diperkirakan dari jumlah penduduk Indonesia yang berjumlah 263.991.379 jiwa, kurang lebih 475.185 orang menderita kanker. Kanker ialah sebuah penyakit yang tidak memiliki penularan dan merupakan permasalahan utama di Indonesia. Menurut World Health Organization tahun 2018 kanker payudara pada perempuan merupakan kanker yang jumlahnya terbesar di Indonesia.

Dalam tahap penyembuhan kanker payudara yakni melalui pembedahan, kemoterapi dan terapi radiasi (Kemenkes RI, 2015). Pengobatan kanker payudara mempunyai efek samping dalam masa pengobatannya. Hal inilah yang menjadi dasar dalam mengembangkan anti kanker alami melalui bahan alami atau derivatnya, oleh karena itu dalam penelitian ini dilakukan uji sitotoksik untuk mengetahuai anti kanker berbasis alami yang dapat mengurangi efek samping yang tidak diinginkan.

Tanaman yang dapat dijadikan antikanker ialah tumbuhan yakon "Smallanthus sonchifolius" yang awalnya terdapat dari Pegunungan Andes di Peru (Lachman et al., 2003). Dari hasil penelitian sebelumnya ekstrak daun yakon terbukti sebagai antikanker, mekanismenya yaitu menginaktivasi sel hela melalui jalur penundaan siklus sel pada fase G2 dan M dan menginduksi apoptosis, aktivasi caspase 3/7 (Kitai, et al., 2016). Di sisi lain dampak protein pada terjadinya apoptosis, seperti protein p53 dan Bcl-2, bisa dikethaui pada mekanisme kerja tumbuhan sebagai agen antikanker. Studi fitokimia daun Yakon menunjukkan adanya kandungan flavonoid dalam senyawa fenolik (Hong et al., 2008). Flavonoid telah memiliki bukti dijadikan agen antikanker, yang mekanismenya menginduksi apoptosis dengan menurunkan bcl-2 (Ren et al., 2003). Dalam Penelitian ini menggunakkan sel T47D dan dan sel vero, sel diberi perlakuan ekstrak daun yakon, fraksi n-heksan, fraksi etil asetat, dan fraksi air. Penelitian ini belum pernah dilakukan sebelumnya.

Metode pengujian sitotoksisitas menggunakan metode analisis MTT, prinsip dari metode ini ialah perubhaan garam tetrazolium (3-(4,5-dimetilazol-2-il)-2,5- difeniltetrazolium bromida (MTT) menjadi formazan dalam mitokondria aktif dalam sel hidup. Selain menguji sitotoksik pada penelitian ini juga menghitung nilai indeks selektivitas yang menunjukkan selektivitas (keamanan) suatu larutan uji terhadap sel normal. Pada penelitian ini digunakan sel vero sebagai sel normal. Ekstrak dan fraksi yang aktif akan dilanjutkan dengan uji imunositokimia untuk mengetahui pengaruh ekspresi protein p53 dan Bcl-2 pada sel kanker payudara T47D. 


\section{Bahan dan metode}

\subsection{Alat dan bahan}

Alat untuk uji sitotoksik MTT dan imunositokimia adalah tangki nitrogen cair, sentrifuge, sentrifuge Sigma 3K12 (B, Braun Biotech International), ELISA reader (SLT 240 ATC), autoklaf, Laminar Air Flow class II (Labconco), Nebauer Haemocytometer, mikroskop terbalik (Axiovert-25), tabung konikal steril, mikroplate 96 sumuran, mesin vortex, tissue cultur flask (Nunclone), lampu ultra violet, neraca elektrik, mikropipet 20-200 $\mu \mathrm{L}$ dan 200-2000 $\mu \mathrm{L}$ (pipetman), inkubator $37^{\circ} \mathrm{C}$, magnetic stirerr dan camera digital. Bahan sampel yang digunakan adalah daun yakon segar dari Mejayan, Kabupaten Madiun, Jawa Timur, sel line T47D, sel Vero, protein p53 dan bcl-2, media RPMI 1640 (Gibco), mesin vortex, tissue cultur flask (Nunclone), HEPES (Sigma), penisilin-streptomisin 1\% v/v (Gibco), DMSO (Dimetil Sulfoksida), Fungision 0,5\% MTT $5 \mathrm{mg} / \mathrm{ml}$, Tripsin 0,5\%, medium M199, larutan PBS, Natrium lauril sulfat $10 \%$ dilarutkan pada $\mathrm{HCl} 0,1 \mathrm{~N}$ sebagai stopper media pencuci sel.

\subsection{Preparasi sampel}

Daun yakon segar yang diambil dari Mejayan, Kab. Madiun, Jawa Timur diidentifikasi dalam membenarkan kredibilitas sampel. Daun yang diambil yang berwarna hijau tua, daun diambil saat tanaman berbunga. Daun dikeringkan dengan oven dalam suhu $40{ }^{\circ} \mathrm{C}$ hingga mengering. Daun yakon yang telah mengering selanjutnya dilakukan penghalusan menjadi serbuk serta dilakukan pengayakan pada ayakan no 40. Serbuk daun yakon kemudian disoxhletasi dengan pelarut etanol 70\% untuk memperoleh ekstrak daun yakon. Ekstrak yang didapatkan kemudian difraksinasi melalui teknik cair-cair menggunakkan pelarut n-heksan, etil asetat dan air.

\subsection{Karakteristik simplisia dan ekstrak}

Mengetahui susut pengeringan simplisia serta ekstrak daun yakon dilakukan melalui alat Moisture Analyzer, yaitu dengan cara menimbang simplisia dan ekstrak masing-masing sebanyak \pm 2 gram. Kemudian Moisture Analyzer ditutup dan ditunggu sampai memberikan tanda dan bunyi, penetapan susut pengeringan diulang sebanyak 3 kali. Penetapan kadar air ekstrak daun yakon dilakukan dengan cara destilasi toluena, penetapan kadar air diulang sebanyak 3 kali.

\subsection{Identifikasi kandungan senyawa kimia}

Kandungan senyawa kimia dalam daun yakon diidentifikasi dengan reaksi tabung dan KLT. Senyawa kimia yang diidentifikasi diantaranya flavonoid, alkaloid dan triterpen. Reaksi tabung flavonoid diidentifikasi dengan reaksi sidal, alkaloid dengan pereaksi dragendrof dan triterpen melalui menambahkan asam sulfat pekat pada dinding tabung. Pada KLT fase diam yang dipergunakan ialah silika gel GF254, pada fase gerak flavonoid kloroform : metanol (8:2), 
alkaloid klorofom : etanol (96:4) dam triterpen N-heksan : etil asetat (1:1).

2.5 Uji sitotoksik

Sel T47D dan sel vero yang telah dipanen dihitung menggunakan Haemocytometer untuk menghitung sel yang dibutuhkan untuk uji sitotoksik, setelah mendapatkan volume yang dibutuhkan ad $10 \mathrm{ml}$ medium komplit. Sel dimasukkan ke dalam mikroplate 96 lubang pada konsentrasi $2 \times 10^{4} \mathrm{sel} /$ sumur $100 \mu \mathrm{l}$, selanjutnya dilakukan penginkubasian dalam waktu 24 jam untuk menyesuaikan dan melekat pada sumuran hingga sel siap dilakukan treatment. Pembuatan larutan stok dengan seri konsentrasi uji pada sel pada medium kultur melalui varians dosis $250 \mu \mathrm{g} / \mathrm{ml}, 125 \mu \mathrm{g} / \mathrm{ml}, 62,5 \mu \mathrm{g} / \mathrm{ml}, 31,25 \mu \mathrm{g} / \mathrm{ml}, 15,625 \mu \mathrm{g} / \mathrm{ml}, 7,81 \mu \mathrm{g} / \mathrm{ml}$. Sampel dimasukkan ke dalam masing-masing mikroplate sesuai seri konsentrasi, diinkubasi 12 jam, setelah itu dilakukan pengujian MTT assay dan dibaca absorbansinya dengan ELISA reader $\lambda 595 \mathrm{~nm}$ dan hitung nilai $\mathrm{IC}_{50}$. Dalam studi ini dipergunakan doksorubisin yang dijadikan kontrol positif.

2.6 Uji imunositokimia

Pemindahan kultur sel hingga 5 x $10^{4} \mathrm{sel} /$ sumur ke 24 sumuran yang diisi melalai kaca penutup, lalu dilakukan penginkubasian sel kedalam inkubator $\mathrm{CO}_{2} 5 \%$ dalam suhu $37^{\circ} \mathrm{C}$ selama 12 jam. Sesudah pemulihan sel, sel tersebut diolah dengan ekstrak dan fraksi pada konsentrasi $\frac{1}{1} 2 \mathrm{IC}_{50}, 1 \mathrm{IC}_{50}$ dan $2 \mathrm{IC}_{50}$, kemudian dilakukan penginkubasian ulang dalam $15 \mathrm{jam}$. Selanjutnya ekstrak dan fraksi aktif dilaksanakan uji imunositokimia melalui metode tidak langsung menggunakkan antibodi primer yaitu antibody anti p53 dan antibodi anti bcl-2. Digunakan Kontrol positif doksorubisin sebagai pembanding. Dengan menggunakan mikroskop inverted ekspresi p53 dan Bcl-2 yang diketahui melalui warna coklat dalam inti sel dan sitoplasma. Pengamatan imunositokimia menggunakan antibodi monoklonal primer, Jika inti sel menghasilkan protein p53 dan Bcl-2 dalam warna coklat/gelap maka positif, dan jika inti sel difiksasi melalui hematoksilin menghasilkan warna ungu, hasilnya negatif. Ekspresi protein p53 dan Bcl-2 dihitung secara kuantitatif menggunakan aplikasi software image $\mathbf{J}$.

\section{Hasil dan pembahasan}

\subsection{Karakteristik ekstrak}

Kadar susut pengeringan pada simplisia serta ekstrak daun yakon diperoleh 8,43\% $\pm 0,057$ dan $6,83 \% \pm 0,015$. Hal ini berdasarkan syarat susut pengeringan pada simplisia kering serta ekstrak yaitu <10 \% (Depkes RI, 2008). Kadar air ekstrak daun yakon diperoleh 7,83\% $\pm 1,04$ $\mathrm{v} / \mathrm{b}$ atau $<10 \%$, bisa diambil simpulan bahwa ekstrak daun yakon sesuai dengan standar, ekstrak dengan kadar air kurang dari $10 \%$ meminimalkan adanya kontaminasi seperti jamur (Depkes RI,2000). 


\subsection{Skrining fitokimia}

Skrining fitokimia dilakukan dengan reaksi tabung dan KLT. Reaksi tabung menunjukkan hasil positif ekstrak mengandung flavonoid, alkaloid dan triterpen. Dari hasil KLT menghasilkan ekstrak ethanol serta fraksi etil asetat positif memiliki kandungan flavonoid dan alkaloid, sedangkan fraksi n-heksan positif mengandung triterpen.

\subsection{Hasil MTT assay dan indeks selektivitas}

Nilai $\mathrm{IC}_{50}$ menghasinya besaran konsentrasi yang bisa menjadi penghambat $50 \%$ sel dalam melakukan proliferasi sel. Nilai IC $_{50}$ dikatakan berpotensi sangat aktif adalah 10-20 $\mu \mathrm{g} / \mathrm{ml}$ dan dikatakan kurang aktif apabila nilainya $\mathrm{IC}_{50}>20 \mu \mathrm{g} / \mathrm{ml}$, apabila nilainya $\mathrm{IC}_{50}<100$ $\mu \mathrm{g} / \mathrm{ml}$ senyawa tersebut tetap memiliki sifat sitotoksik terhadap sel kanker. Hasil studi menghasilkan bahwasanya ekstrak etanol daun yakon dan fraksi etil asetat daun yakon menunjukkan kegiatan sitotoksik yang nilainya $\mathrm{IC}_{50} 73,47 \mu \mathrm{g} / \mathrm{ml}$ dan $56,84 \mu \mathrm{g} / \mathrm{ml}$, sedangkan fraksi air dan fraksi n-heksan memiliki nilai $\mathrm{IC}_{50}$ lebih dari $100 \mu \mathrm{g} / \mathrm{ml}$ yang artinya tidak menunjukkan aktivitas sitotoksik. Ekstrak dan fraksi daun yakon dihitung nilai indeks selektivitas, indeks selektivitas diperoleh dari nilai $\mathrm{IC}_{50}$ sel vero dibagi nilai $\mathrm{IC}_{50}$ sel T47D. Selektivitas menunjukkan bahwa ekstrak dan fraksi hanya menyerang sel kanker saja sedangkan sel normal tidak. Nilai indeks selektivitas lebih dari 3 menunjukkan selektif hanya menyerang sel kanker sedangkan pada sel normal tidak menyerang (Rahmawati et al., 2016). Nilai indeks selektivitas menunjukkan keamanan pada sel normal (Alali et al., 1999).

Larutan uji yang menunjukkan aktivitas sitotoksik dan memiliki indeks selektivitas lebih dari 3 menunjukkan keamanan terhadap sel normal dan bersifat sitotoksik pada sel kanker sehingga dilanjutkan dengan uji imunositokimia untuk melihat ekspresi protein p53 dan bcl-2 yang berpengaruh pada apoptosis. Dari hasil studi menghasilkan ekstrak dan fraksi etil asetat mempunyai aktivitas sitotoksik dan nilai indeks selektivitas lebih dari 3. Ekstrak dan fraksi etil asetat dilanjutkan ke uji imunositokimia.

Tabel 1.Hasil MTT assay dan nilai indeks selektivitas ekstrak daun yakon (Smallanthus sonchifolius), fraksi N-heksan, fraksi etil asetat dan fraksi air pada sel kanker payudara T47D.

\begin{tabular}{|c|c|c|c|}
\hline Sampel & $\begin{array}{c}\text { IC }_{50} \text { Sel vero } \\
(\mu \mathrm{g} / \mathrm{ml})\end{array}$ & $\begin{array}{c}\text { IC }_{50} \text { Sel T47D } \\
(\mu \mathrm{g} / \mathrm{ml})\end{array}$ & Nilai indeks selektivitas \\
\hline Ekstrak & $330,98 \pm 34,59$ & $73,47 \pm 4,93$ & 4,50 \\
\hline Fraksi N-heksan & $64,39 \pm 6,71$ & $187,33 \pm 24,44$ & 0,34 \\
\hline Fraksi Etil Asetat & $268,35 \pm 17,47$ & $56,84 \pm 3,52$ & 4,72 \\
\hline Fraksi Air & $5358,97 \pm 19,19$ & $780,36 \pm 22,51$ & 6,86 \\
\hline Kontrol Positif & $66,08 \pm 14,00$ & $12,54 \pm 3,80$ & 5,26 \\
\hline
\end{tabular}

3.4 Hasil imunositokimia

Pengujian imunositokimia dilakukan pada empat pengelompokkan perlakuan yakni kelompok tanpa perlakuan (kontrol sel), kontrol positif, kelompok pada pemberian ekstrak daun 
yakon dengan masing masing konsentrasi $1 / 2 \operatorname{IC}_{50}(36,73 \mu \mathrm{g} / \mathrm{ml}), 1 \mathrm{IC}_{50}(73,47 \mu \mathrm{g} / \mathrm{ml}), 2 \mathrm{IC}_{50}$ $(146,94 \mu \mathrm{g} / \mathrm{ml})$, fraksi etil asetat dengan masing masing konsentrasi $1 / 2 \mathrm{IC}_{50}(28,42 \mu \mathrm{g} / \mathrm{ml}), 1$ $\operatorname{IC}_{50}(56,84 \mu \mathrm{g} / \mathrm{ml}), 2$ IC $_{50}(113,68 \mu \mathrm{g} / \mathrm{ml})$.

Tabel 2. Hasil peningkatan ekspresi p53 ekstrak dan fraksi etil asetat daun yakon (Smallanthus sonchifolius) pada sel kanker payudara T47D.

\begin{tabular}{|c|c|c|c|c|}
\hline Perlakuan & $\begin{array}{c}\begin{array}{c}\text { Konsentrasi } \\
(\mu \mathrm{g} / \mathrm{ml})\end{array} \\
\end{array}$ & $\begin{array}{c}\text { Rata-rata } \\
\text { Ekspresi p53 } \pm \text { SD }\end{array}$ & $\begin{array}{c}\text { Peningkatan } \\
\text { Ekspresi p53 }(\%) \pm \mathrm{SD}\end{array}$ & $\begin{array}{c}\mathrm{EC}_{50} \pm \mathrm{SD} \\
(\mu \mathrm{g} / \mathrm{ml})\end{array}$ \\
\hline Ekstrak & $1 / 2 \mathrm{IC}_{50}(36,73)$ & $10,92 \pm 0,85$ & & \multirow{4}{*}{$\begin{array}{c}32,21 \pm \\
12,81\end{array}$} \\
\hline etanol daun & $1 \mathrm{IC}_{50}(73,47)$ & $14,61 \pm 0,67$ & $114,25 \pm 2,12$ & \\
\hline yakon & $2 \operatorname{IC}_{50}(146,94)$ & $18,28 \pm 0,54$ & $168,04 \pm 1,11$ & \\
\hline Fraksi etil & $1 / 2 \mathrm{IC}_{50}(28,42)$ & $10,10 \pm 0,67$ & $48,12 \pm 4,35$ & \\
\hline asetat & $1 \mathrm{IC}_{50}(56,84)$ & $16,04 \pm 3,91$ & $135,13 \pm 9,65$ & \multirow{4}{*}{$\begin{array}{c}28,77 \pm \\
18,36\end{array}$} \\
\hline $\begin{array}{l}\text { ekstrak daun } \\
\text { yakon }\end{array}$ & $2 \mathrm{IC}_{50}(113,68)$ & $21,85 \pm 2,51$ & $220,23 \pm 3,88$ & \\
\hline $\begin{array}{l}\text { Kontrol } \\
\text { positif }\end{array}$ & & $15,11 \pm 1,44$ & & \\
\hline Kontrol sel & & $6,82 \pm 0,87$ & & \\
\hline
\end{tabular}

Dari tabel 2 hasil imunositokimia menunjukkan pemberian ekstrak etanol atau fraksi etil asetat daun yakon dengan berbagai kelompok perlakuan dapat meningkatkan ekspresi protein p53 dengan nilai EC50 (EC50 menunjukkan konsentrasi ekstrak atau fraksi yang dapat meningkatkan $50 \%$ ekspresi protein p53) $32,21 \mu \mathrm{g} / \mathrm{ml}$ dan $28,77 \mu \mathrm{g} / \mathrm{ml}$. Fungsi utama p53 adalah mengelola dan mengendalikan siklus sel dan respon sel pada rusaknya DNA, inisiasi replikasi serta memperbaiki DNA, induksi apoptosis dan promosi diferensiasi sel. P53 dapat menginduksi enzim yang betujuan perbaikan DNA. Jika rusaknya DNA sel tidak dapat dilakukan perbaikan, p53 akan memandu sel dalam terjadinya kematian dalam jalur apoptosis. Dengan demikian p53 memiliki peran dalam merespons kerusakan DNA, yaitu menghambat progresi siklus sel dan mengarahkan pada jalur apoptosis bila kerusakan DNA tidak dapat diperbaiki lagi (Leong et al., 1995).

Tabel 3. Hasil penurunan ekspresi Bcl-2 ekstrak dan fraksi etil asetat daun yakon (Smallanthus sonchifolius) pada sel kanker payudara T47D.

\begin{tabular}{|c|c|c|c|c|}
\hline Perlakuan & $\begin{array}{l}\text { Konsentrasi } \\
(\mu \mathrm{g} / \mathrm{ml})\end{array}$ & $\begin{array}{c}\text { Rata-rata } \\
\text { Ekspresi Bcl-2 } \pm \\
\text { SD }\end{array}$ & $\begin{array}{l}\text { Penurunan Ekspresi } \\
\text { Bcl-2 }(\%) \pm \text { SD }\end{array}$ & $\begin{array}{c}\mathrm{EC}_{50} \pm \mathrm{SD} \\
(\mu \mathrm{g} / \mathrm{ml})\end{array}$ \\
\hline \multirow{3}{*}{ Ekstrak } & $1 / 2 \operatorname{IC}_{50}(36,73)$ & $13,03 \pm 2,9$ & $38,20 \pm 13,73$ & \multirow{3}{*}{$55,46 \pm 19,80$} \\
\hline & $1 \mathrm{IC}_{50}(73,47)$ & $8,84 \pm 1,08$ & $58,06 \pm 5,12$ & \\
\hline & $2 \operatorname{IC}_{50}(146,94)$ & $4,67 \pm 0,93$ & $77,81 \pm 4,43$ & \\
\hline \multirow{3}{*}{$\begin{array}{l}\text { Fraksi etil } \\
\text { asetat }\end{array}$} & $1 / 2 \operatorname{IC}_{50}(28,42)$ & $11,63 \pm 0,59$ & $44,80 \pm 2,79$ & \multirow{3}{*}{$34,52 \pm 17,04$} \\
\hline & $1 \mathrm{IC}_{50}(56,84)$ & $7,78 \pm 1,57$ & $63,07 \pm 7,43$ & \\
\hline & $2 \mathrm{IC}_{50}(113,68)$ & $4,45 \pm 0,2$ & $78,86 \pm 0,95$ & \\
\hline Kontrol positif & $\mathrm{IC}_{50}$ & $8,70 \pm 2,19$ & & \\
\hline Kontrol sel & & $21,08 \pm 2,15$ & & \\
\hline
\end{tabular}

Pemberian ekstrak etanol atau fraksi etil asetat daun yakon dengan berbagai kelompok perlakuan dapat menurunkan ekspresi protein bcl-2 dengan nilai $\mathrm{EC}_{50} 55,46 \mu \mathrm{g} / \mathrm{ml}$ dan 34,52 
$\mu \mathrm{g} / \mathrm{ml}$. Pada sel kanker, meningkatnya ekspresi yang bisa menghambat fungsi normal protein proapoptosis diakibatkan oleh mutasi pada gen bcl-2. Mutasi pada bcl-2 bisa diturunkan dan mengakibatkan hilangnya sel pada kemampuannya dalam mengatur apoptosis, yang mengakibatkan kanker (Lumongga, 2008).

Ekstrak etanol dan fraksi etil asetat daun yakon mengandung flavonoid dan alkaloid. Mekanisme flavonoid sebagai antikanker yaitu penghambatan aktivitas DNA topoisomerase I/II, dimana enzim ini berfungsi pengontrol topologi DNA, dengan adanya inhibitor menyebabkan rusaknya DNA sel kanker yang berdampak dalam replikasi sel dan diakhiri pada kematian sel, selain itu mekanisme flavonoid juga menyebabkan turunnya ekspresi protein bcl2 dan bcl-xl dan aktivasi endonuclease, menginhibisi aktivitas protein kinase (Ren et al., 2003). Mekanisme alkaloid berkaitan dengan tubulin pada siklus sel, tubulin ialah sebuah protein yang membentuk mikrotubulus. Kombinasi tubulin dan alkaloid menghasilkan penghambatan polimerisasi protein menjadi mikrotubulus, yang juga akan menghambat terbentuknya spindel mitotic dan menghentikan siklus sel metafase. Dikarenakan tidak bisa melaksanakan pembelahan sel, sel-sel ini akan terjadi apoptosis (Bertomi, 2011).

\section{Kesimpulan}

Dari hasil penelitian dapat disimpulkan bahwasanya ekstrak dan fraksi etil asetat daun yakon "Smallanthus sonchifolius" mempunyai kegiatan sitotoksik pada sel kanker payudara T47D, melalui nilai IC 50 masing-masing sebesar $73.47 \mu \mathrm{g} / \mathrm{ml}$ dan $56.84 \mu \mathrm{g} / \mathrm{ml}$, sedangkan NHeksan dan fraksi air tidak mempunyai kegiatan sitotoksik, melalui nilai $\mathrm{IC}_{50}>100 \mu \mathrm{g} / \mathrm{ml}$. Indek selektivitas ekstrak dan fraksi etil asetat daun yakon (Smallanthus sonchifolius) dan fraksi etil asetat pada sel kanker payudara T47D dibandingkan pada sel vero $\geq 3$. Ekstrak dan fraksi etil asetat daun yakon meningkat ekspresi protein p53 pada sel kanker payudara T47D melalui $\mathrm{EC}_{50} 32,21 \mu \mathrm{g} / \mathrm{ml}$ dan $28,77 \mu \mathrm{g} / \mathrm{ml}$. Ekstrak dan fraksi daun yakon (Smallanthus sonchifolius) terjadi penurunan ekspresi protein bcl-2 pada sel kanker payudara T47D melalui $\mathrm{EC}_{50}$ sebesar $55,46 \mu \mathrm{g} / \mathrm{ml}$ dan $34,52 \mu \mathrm{g} / \mathrm{ml}$.

\section{Ucapan Trimakasih}

Terimakasih kepada Fakultas Farmasi Universitas setia Budi Surakarta atas fasilitas yang sudah dan diberikan.

\section{Deklarasi Konflik Kepentingan}

Semua penulis menyatakan tidak ada konflik kepentingan terhadap naskah ini.

\section{Daftar Pustaka}

Alali, F.Q., Liu, X.X. and McLaughlin, J.L. (1999). Annonaceous Acetigenins: Recent Progress Journal of Natural Product. 62(3): 504-40. 
Bertomi R. P. (2011). Uji Toksisitas Akut Ekstrak Kulit Batang Pulasari (Alyxiae cortex) dengan Metode Brine Shrimp Lethality Test (BST), Skripsi Sarjana, Program Studi Farmasi Fakultas Farmasi Universitas Sanata Dharma Yogyakarta, h. 6

Departemen Kesehatan Republik Indonesia. (2000). Parameter Standar Umum Ekstrak Tumbuhan Obat, Departemen Kesehatan Republik Indonesia, Jakarta, Indonesia.

Departemen Kesehatan Republik Indonesia. (2008). Farmakope Herbal Indonesia, Edisi I, Departemen Kesehatan Republik Indonesia, Jakarta, Indonesia.

Hong, S.S., Lee, S.A., Han, X.H., Lee M.H., Hwang, J.S., Park, J.S. (2008). Melampolides from the leaves of Smallanthus sonchifolius and their inhibitory activity of lps induced nitric oxide production. Chem Pharm Bull, 56:199-202.

Kemenkes RI. (2015). Panduan Penatalaksanaan Kanker Payudara. Diakses pada 26 April 2017 dari http://kanker.kemkes.go.id/guidelines/PPKPayudara.pdf

Kitai, Y., Xia, Z., Yushi, H., Hiritoshi, T. (2016). Induction of G2/M Apoptosis Through Mitocondria Pathway by a dimer sesquiterpene lactone from Smallanthus sonchofolius in hela cells. Journal of Food and Drug Analysis, 25(3), p619-627.

Lachman, J., Fernández, E. C., Orsák. M. (2003). Yacon [Smallanthus sonchifolia (Poepp. et Endl.) H. Robinson] chemical composition and use - a review. Plant, Soil Environ, 49, 283-290.

Leong, A.S.Y., Robbins, P., Spagnalo, D.U. (1995). Relevance and Detection System of Tumor Genes and Their Proteins in Cytologic and Surgical Specimens. Jakarta International Cancer Conference, 1-26.

Lumongga F. (2008). Apoptosis. Medan : Departemen patologi anatomi fakultas kedokteran Universitas Sumatera Utara.

Rahmawati, I.S., Herwandhani, P., Edy, M. (2016). Selektivitas Ekstrak Etanolik Buah Makassar (Brucea javanica) pada Kanker Payudara Metastasis secara In Vitro. Journal of Agromedicine and Medical Sciences, 2(1).

Ren, W., Qiao, Z, Wang, H., Zhu, L., Zhang, L. (2003). Flavonoids: promising anticancer agents. Medicinal Research Reviews, 23(4): 519-534.

Riset Kesehatan Dasar. 2018. Badan Penelitian dan Pengembangan Kesehatan Kementerian RI

http://www.depkes.go.id/resources/download/infoterkini/materi_rakorpop_2018/Hasil \%20Riskesdas\%202018.pdf - Diakses Agustus 2018.

Torre, L.A, Bray, F., Siegel, R.L., Ferlay, J., Lortet-Tieulent, J., Jemal, D.A. (2015). Global cancer statistics. Cancer J Clin, (65):87e108.

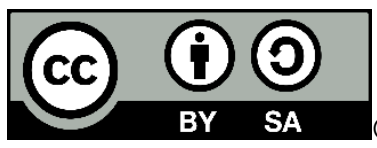

2021 by the authors. Submitted for possible open access publication under the terms and conditions of the Creative Commons Attribution-ShareAlike 4.0 International (CC BY-SA 4.0) license (https://creativecommons.org/licenses/by-sa/4.0/). 